\title{
DÜBLIN
}

Technological University Dublin

ARROW@TU Dublin

2009-11-01

\section{How Does Politics Affect Electronic Healthcare Adoption}

\author{
Zanifa Omary \\ Technological University Dublin, zanifa.omary@student.dit.ie \\ Fredrick Mtenzi \\ Technological University Dublin, Fredrick.Mtenzi@tudublin.ie \\ Bing Wu \\ Technological University Dublin, bing.wu@tudublin.ie
}

Follow this and additional works at: https://arrow.tudublin.ie/futuresaccon

Part of the Computer Sciences Commons

\section{Recommended Citation}

Omary, Z., Mtenzi, F., Wu, B.: How does Politics Affect Electronic Healthcare Adoption. 4th International Conference for Internet Technology and Secured Transactions, London, UK. November 9-12, 2009.

This Conference Paper is brought to you for free and open access by the Futures Academy at ARROW@TU Dublin. It has been accepted for inclusion in Conference papers by an authorized administrator of ARROW@TU Dublin. For more information, please contact arrow.admin@tudublin.ie, aisling.coyne@tudublin.ie, gerard.connolly@tudublin.ie.

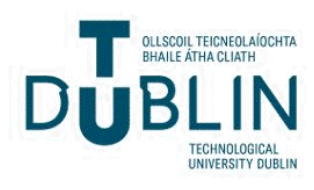




\title{
How does Politics Affect Electronic Healthcare Adoption
}

\author{
Zanifa Omary, Fredrick Mtenzi, Bing Wu \\ School of Computing \\ Dublin Institute of Technology \\ zanifa.omary@student.dit.ie, \{fredrick.mtenzi, bing.wu\}@dit.ie
}

\begin{abstract}
In the 21 century, the term e-healthcare has become the common buzzword in the world. Its popularity is directly related to the rate of its adoption and benefits that it offers to individuals and governments. Among the common benefits include reduction in medical errors, improvements on physician efficiency, improvement in physician-patient relationship and an increase in the quality of care delivered. Despite all these benefits, politics is one among the obstacles hindering its adoption. In this paper we analyse how politics at local, national and international levels affect e-healthcare adoption and thereafter we suggest appropriate alternatives to overcome these obstacles.
\end{abstract}

